\title{
COMPARATIVE STUDY ON THE RABBIT FISHES SIGANUS CANALICULATUS INHABIT THE ARABIAN GULF AND SIGANUS RIVULATUS INHABIT THE RED SEA IN SAUDI ARABIA
}

\author{
Adel A. Tharwat and Mohammed A. Al-Owafeir \\ Depart. of Aquatic Res. Fac. of Agric. Sciences and Food \\ King Faisal University, PO Box 420, Hofuf, 31982 Saudi Arabia
}

Keywords: fish, Siganus, Arabian Gulf, Red Sea, biology, minerals, heavy metals, fatty acids.

\section{ABSTRACT}

$\mathrm{T}$ The present work was carried out to compare some biological aspects, chemical composition, fatty acids, minerals and heavy metals of the commercial Rabbit fishes Siganus canaliculatus inhabit the Arabian Gulf and Siganus rivulatus inhabit the Red Sea in Saudi Arabia. Fish samples were selected to represent all fish size categories in the catch and were collected during the period from November 2002 to March 2003. Each fish specimen was measured, weighted and recorded, then dissected to investigate the fullness of alimentary canal and the maturity stage of the gonads. The lengthweight relationships were computed by simple regression analysis and graphically represented. Both of absolute and relative condition factors $(\mathrm{Kc}$ and $\mathrm{Kn})$ were estimated and graphically represented. The muscles (flesh) were removed and weighted to estimate the flesh percentage. Samples of flesh were taken to determine moisture, protein, ether extract, ash, fatty acids, minerals and heavy metals. Some samples of the entire fish were used to proximate analysis. The present results indicated that the $\mathrm{Kc}, \mathrm{Kn}$, maximum total length and flesh percentage of Rabbit fish Siganus canaliculatus were higher than that of Siganus rivulatus. In general, polyunsaturated fatty acids were relatively low and heavy metal concentrations in the flesh of the two Siganus species were lower than the permit limits for Human consumption. 


\section{INTRODUCTION}

The Siganus fishes are small to moderate in size and belong to family Siganidae. They are herbivore fishes and feed by nibbling the marine vegetation, usually grazing in schools with head directed downwards, so, they live mainly around coral reefs and weedy areas. Their bodies are compressed, oval in out line and covered with minute scales that are smooth in touch. The small mouth is equipped with a row of close-set teeth in each jaw. They have poisonous dorsal and anal spines for armour. The mucus covering the spines is toxic and although not fatal to man, can produce unpleasant swelling and pain. For this reason they should be handled with care. Siganus fishes have important commercial value; most species are good, desirable for consumption and fetch medium to high prices in the markets. Although Siganus fishes have relatively small sizes they are extremely tasty and much demand in the markets, especially on the Gulf coast. There are five common species in Saudi Arabia, two of them $S$. rivulatus and $S$. stellatus inhabit the Red Sea (Wray, 1979) and the others $S$. canaliculatus, $S$. javus and $S$. luridus inhabit the Arabian Gulf (Al-Baharna, 1986). The two species $S$. rivulatus and $S$. canaliculatus are more abundant and have a highly commercial value than the others in Saudi Arabia. The first native species, Siganus rivulatus, is successfully cultured on the Red Sea coast of Saudi Arabia. Siganus fishes are caught mainly by the gill nets and beach seines. Some biological studies were done on Siganus fishes in many countries (Wray, 1979; Basson et al., 1981; Hashem, 1983; ElGammal, 1988; Chan, 1995; Lai Man So et al., 1999 and Bilecenoglu, 2002), but few of them were contributed to territorial waters of Saudi Arabia. Therefore, the present work was performed to compare some biological aspects and chemical composition of Rabbit fishes $S$. canaliculatus and $S$. rivulatus harvested from the natural fisheries of the Arabian Gulf and Red Sea in Saudi Arabia.

\section{MATERIALS AND METHODS}

Specimens of the two native species $S$ canaliculatus and $S$. rivulatus of all fish size categories represented in the catch were collected from the Arabian Gulf and the Red Sea during the period from November 2002 to March 2003. Fish total length to the nearest $0.1 \mathrm{~cm}$ and fish total weight to the nearest $0.1 \mathrm{gm}$ were recorded. 
Fishes were dissected to investigate the fullness of alimentary canal and the maturity stage of the gonads. Absolute condition factors $(\mathrm{Kc})$, relative condition factors $(\mathrm{Kn})$ and length-weight relationship were computed as in Ricker (1975). The muscles (flesh) were removed and weighed to estimate the flesh percentage. The flesh was taken to determine the moisture, protein, ether extract, ash, minerals and heavy metals according to AOAC (1995), also sub-samples of entire fishes were taken to proximate analyses. Fatty acids were analyzed by following the standard methods of IUPAC (1979). Simple regression, standard deviation, analysis of variance (ANOVA) and differences in mean values were estimated using the program of SAS (1990).

\section{RESULTS AND DISCUSSION}

\section{Length frequency distribution:}

Table (1) shows some values of biological aspects of $S$. canaliculatus inhabit the Arabian Gulf and $S$. rivulatus inhabit the Red sea. Fish total lengths ranged between $15-32 \mathrm{~cm}$ with an average length of $22.93 \pm 2.75 \mathrm{~cm}$ for $S$. canaliculatus, and ranged between $15-27 \mathrm{~cm}$ with an average length of $20.23 \pm 1.84 \mathrm{~cm}$ for $S$. rivulatus. It was obvious that $S$. canaliculatus has larger size than $S$. rivulatus. Length frequency distribution in Figure (1) displayed two normal distribution curves for both Siganus species; when the majority of fishes were belong to length categories of $18-27 \mathrm{~cm}$ for $S$. canaliculatus and length categories of $16-24 \mathrm{~cm}$ for $S$ rivulatus. Fish size at first recruitment in the catch was relatively small and equal to $15 \mathrm{~cm}$ total length for both species. This result may be supported with the actual using of similar fishing gears with equal mesh size to catch Siganus fishes in coastal waters of the Arabian Gulf and Red Sea. However, the maximum total length in $S$. canaliculatus is longer $(32 \mathrm{~cm})$ than in $S$. rivulatus $(27 \mathrm{~cm})$ that may be related to the low exploitation rate or fishing effort in the Arabian Gulf in comparing with the Red sea.

\section{Length-weight relationship:}

The results in Table (1) indicate that $S$. canaliculatus has heavier body weights than $S$. rivulatus, when it ranged between $54-$ $519 \mathrm{gm}$ with an average of $152.56 \pm 63.87 \mathrm{gm}$, and it ranged between $53-248 \mathrm{gm}$ with an average of $109.69 \pm 30.17 \mathrm{gm}$, respectively. Length-weight relationships for both species are graphically 
represented in Figure (2). It can be observed that the length increment responding with a highly increase in weight to consist an exponential relationship, which relatively higher in $S$. canaliculatus than $S$. rivulatus. Consequently, two equations were extracted for describing the relationship between weight and length for the two species as follows:

For $S$. canaliculatus: $\mathrm{W}=0.006 * \mathrm{~L}^{3.28}(\mathrm{r}=0.9978)$ or Log. $W=-2.25+3.28 \log . \mathrm{L}$,

$$
\begin{array}{r}
\text { For S. rivulatus: } \mathrm{W}=0.013^{*} \mathrm{~L}^{2.99}(\mathrm{r}=0.9589) \\
\text { or } \mathrm{Log} . \mathrm{W}=-1.88+2.99 \mathrm{Log} . \mathrm{L}
\end{array}
$$

Where: $W$ is the total weight of fish (gm), $L$ is the total length of fish $(\mathrm{cm})$ and $\mathrm{r}$ is the correlation coefficient. The high values of $\mathrm{r}$ indicate a good measure for the strength of these equations and closeness of observed and calculated values of fish weight. On the other hand, the regression parameters $(\mathrm{a}, \mathrm{b}$ and $\mathrm{r}$ ) in the present study agree with the results obtained by Bilecenoglu (2002) on Siganus rivulatus in the Mediterranean Sea. He found that regression constant parameters for combined sexes are as follow: $a=0.007, b=3.179, r=0.95$. However, Lai Man So et al. (1999) investigated Siganus oramin collected frmm Tolo Harbour and Victoria Harbour in Hong Kong and outside Hong Kong. They found that the average fish weights were $56.3,33.0,234.3 \mathrm{gm}$ for the three regions, respectively. From the present results and that of Lai Man So et al. (1999) we can conclud that the growth rate and maximum fish size were strongly differ for the same species in the different habitats.

\section{Condition factor}

The average values of absolute condition factor $(\mathrm{Kc})$ and relative condition factor $(\mathrm{Kn})$ are shown in Table (1). Kc and $\mathrm{Kn}$ values according to fish length are graphically represented in Figures (3) and (4), respectively. The present results revealed that the $\mathrm{Kc}$ values were fluctuated between $1.1-1.4$ with an average of 1.29 for Siganus canaliculatus inhabit the Arabian Gulf and between 1.1-1.3 with an average of 1.24 for Siganus rivulatus inhabit the Red sea. The graphical representation for both fish species shows a similar fluctuation pattern of $\mathrm{Ke}$ values, which indicates a gradual increase in $\mathrm{Kc}$ values with the increase of fish length. Generally, The mean $\mathrm{Kc}$ value of Siganus canaliculatus is significantly higher than of Siganus rivulatus. However, the mean values of the relative condition factor $(\mathrm{Kn})$ are not significantly different between the two Siganus species. 
$\mathrm{Kn}$ values fluctuated between $0.92-1.17$ with an average of 1.06 for Siganus canaliculatus and between $0.9-1.12$ with an average of 0.99 for Siganus rivulatus (Table 1). The graphical representation of $\mathrm{Kn}$ values (Fig. 4) for both species showed a gradual increase in $\mathrm{Kn}$ values with increase in fish length. On the other hand, the investigation of all dissected fishes for the two Siganus species showed that the majority of fish gonads were undeveloped or immature; inversely the digestive canals of most fishes were full with herbs and algae. Consequently, high values of the Kn for the Siganus fish may be related to the suitable of habitat ecology of both the Arabian Gulf and Red Sea for the Siganus species, which lead to a high feeding activity and body fullness. This result is agreed with the study of Zaki et al. (1996) on gonadal development of Siganus rivulatus, where they found that the of oocytes were very small during November to February, while developing oocytes started from March.

\section{Flesh percentage:}

The flesh percentage for the two Siganus species, which mean the percentage of fillet or muscles (\%) are shown in Table (1) and represented graphically in Figure 5. The overall average of flesh percentages was significantly higher $(50.39 \%)$ for Siganus canaliculatus inhabit the Arabian Gulf than in Siganus rivulatus $(48.93 \%)$ inhabit the Red Sea. The flesh percentage increases with fish size increment for both Siganus species and displayed a sigmoid curve pattern, which starting by a gradual increase rate followed with a gradual decrease in flesh increment. The data refer to the priority of flesh percentage of all fish sizes for $S$. canaliculatus than for $S$. rivulatus. This result was related to the variability in the fullness or the condition factor between the two Siganus species.

\section{Chemical composition:}

The results of proximate analysis of muscles and entire body of the two Siganus species are shown in Table (2). It was obvious that Siganus rivulatus has higher protein content and lower fat content than Siganus canaliculatus. However, the ash content is slightly higher in the muscles and slightly lower in the body entire of Siganus canaliculatus comparing with Siganus rivulatus. It is well known that the chemical composition of fish is affected by the season of the year, food abundance and the physiological status (Egan et al., 1981). The 
protein and fat contents were relatively lower in the present results than that of Elgasim (1994), when he studied the chemical composition of some carnivorous fishes from the Arabian Gulf. $\mathrm{He}$ found high protein content $; 21.28 \%, 19.82 \%, 19.05 \%, 20.32 \%$ and high fat content $4.50 \%, 3,56 \%, 4,18 \%, 2,06 \%$ for Kanad Scomberomorus commerson, Hamour Epinephalus chlorostigma, Hamrah Lutjanus malabericus and Shaeiry Lethrinus lentjan, respectively. These differences of protein and fat contents may be due to 1) high nutritional requirements of protein for carnivorous fishes than in herbivorous fishes (Boonyaratpalin, 1997), 2) the enzymes for protein and fat digestion are more effective in carnivorous fishes than in herbivorous fishes (Al-Owafeir, 1999). Consequently, the herbivorous one such Siganus species must contain lower content of protein and fat than in the carnivorous fishes such Kanad, Hamour, Hamrah and Shaeiry.

\section{Fatty acids:}

The fatty acid profiles of muscles (flesh) of Siganus canaliculatus and Siganus rivulatus are listed in Table (3). As a general, it would be noticed that the fatty acids concentration in the muscles of $S$. rivulatus is higher than in $S$. canaliculatus. The quantity and quality of fat content in fisbes are affected by feed quality, water quality, spawning season, fish migration, fish size and starvation (Hardy and King, 1989). So, the level of individual fatty acids in fish depends, of course, on the total fat content, and the percentage of fatty acids distribution changes as the fat content of the fish rises and falls. When the fat content increases, the contribution of the monosaturated fatty acids increases from around 30 to $50 \%$, while the level of polysaturated fatty acids decreases from 50 to $20 \%$ (Childs and King, 1993). Generally, herbivorous fishes and properly Siganus fishes are belong to medium fat category. Table (3) shows that Palmitic acid (16:0) which is the primary saturated fatty acid, constitutes $32 \%$ and $31.90 \%$ of the total fatty acids in the muscles of $S$. rivulatus and $S$. canaliculatus, respectively. Oleic acid (18:1) represents the highest concentration of monounsaturated fatty acids in the muscles, which constitutes $11.09 \%$ and $10.40 \%$ for $S$. rivulatus and $S$. canaliculatus, respectively. These results due to the Palmitic acid $(16: 0)$ consider the most important and necessary fatty acid for structure and physiology of cell membrane in fishes $(\mathrm{Ng}$ ef al., 2003), while the high concentration of Oleic acid (18:1) may be related to its 
major role in fat metabolism. The same trend was observed in animal and plant tissues (Querijero et al., 1997). The total saturated and monounsaturated fatty acids represent the majority component of the total fatty acids that constitute $69.67 \%$ and $64.68 \%$ for $S$. rivulatus and $S$. canaliculatus, respectively (Table 3 ). This result is in agreement with other studies on different fish species (Montano et al., 2001; Gessner et al., 2002; Ng et al., 2003). This may be contributed to the similar metabolism processes in synthetics fatty acids (Steffens, 1989). On the other hand, the linolenic acid (18:3) concentration is approximately duplicated in $S$. rivulatus (1.26) than of $S$. canaliculatus (0.66). Similar result was pointed for $S$. canaliculatus (0.7) from the Arabian Gulf in the coast of Qatar (Al-Jedah et al., 1999). According to Montano et al., (2001) the linolenic acid consider the primary polyunsaturated fatty acid that many of long chain unsaturated fatty acids belongs to Omiga3 were derived from it. Generally, the linolenic acid concentration was low in Siganus muscles comparing with other fish species such as the gilthead seabream Sparus aurata in wild and aquaculture (Grigorakis et al., 2002), the African Catfish Clarias gariepinus (Ng et al., 2003) and sea bass Dicentrarchus labrax (Alasaivar et al., 2002).

Becouse Siganus species belong to herbivorous fishes, so their natural food contain a low concentration of the long chain unsaturated fatty acids comparing with the artificial diets which supplemented with different types of fish oil. This result revealed the role of diet component on the fatty acids content in fish muscles (Kherunnisa $e t$ $a l .$, 1996). On the other hand, Wodtke, (1981) indicated that the temperature has a good effect on the type and quantity of fatty acids in fishes.it is known that the percentage of long chain polyunsaturated fatty acids In crease in cold-water fishes than in warm-water fishes, and vice versa for the long chain saturated and monounsaturated fatty acids. In the present results, it obvious that the percentage of long chain polyunsaturated fatty acids in Siganus fish was lower than in cold-water fishes such Cod fish (Meeren et al., 1993) and in Arctic charr fish (Olsen and Henderson, 1997).

\section{Minerals and heavy metals:}

The minerals and heavy metals composition of the flesh of $S$. canaliculatus inhabiting the Arabian Gulf and $S$. rivulatus inhabiting the Red Sea are shown in Table (4). It can be noticed that the roncentration of Sodium $(\mathrm{Na}$ ). Potassion ( $\%$ ) and Magnesium $(\mathrm{Mg})$ 
were higher in $S$. canaliculatus than S. rivulatus, while Calcium (Ca) displayed an inverse pattern. This may be related to the higher water salinity of the Arabian Gulf than that of the Red Sea. Likewise, the heavy metals concentrations including Lead $(\mathrm{Pb})$, Zinc $(\mathrm{Zn})$, Copper $\mathrm{Cu}$ and Manganese $(\mathrm{Mn})$ were higher in $S$. canaliculatus than those in $S$. rivulatus except for Iron, which displayed an inverse picture. Among the heavy metals it was found that the concentrations of Cadmium (Cd), Arsenic (As) and Aluminum (Al) in the flesh of two Siganus species were lower than the detection limits $(<0.001)$. This result may contribute to the variation of ecological factors of the Arabian Gulf and the Red Sea. Where, there are many industrial activities such as petroleum purification stations, petrochemicals manufactories, and oil transportations in the Arabian Gulf. These reasons lead to increase the heavy metals concentrations in the Gulf water, that accumulate finally in the tissues of fishes and other living aquatic organisms. According to NRC (1985) about $4.7 \%$ of total oil pollutants of the world is occurred in the Arabian Gulf. The present results are in agreement with the results of Al-Jedah et al. (1999) on $S$. canaliculatus harvested from the Arabian Gulf in Qatar. This is well understands because the ecological conditions in territorial waters on the Arabian Gulf for both Saudi Arabia and Qatar are the same. Otherwhere, Lai Man So et al., (1999) were studied the heavy metals concentration in muscles of $S$. oramin collected from Tolo Harbour, Victoria Harbour, and outside Hong Kong and they found a similar results, that indicates to the similarity of the environmental conditions in the two regions. On the other hand, comparison between the present results and the study of Al-Saleh and Shinwari (2002), they found more than ten-times concentrations of heavy metals in the muscles of Siganus fishes in Darien, Manifa, Al-damam in the Arabian Gulf coast of Saudi Arabia compared by the present result. They commented that their fish samples were collected in areas receive the agriculture and sewage drainage, which caused the highly water pollution with heavy metals. It is well known that the heavy metals absorb through the gill surface, skin or feed intake, but the absorption efficiency depend on fish species, water quality and ecological factors such as water temperature and salinity (Canli and Furness, 1995).

On the other hand, some authors found the high concentrations of heavy metals in some fish species for example; Canli and Atli (2003) indicated that the muscles of Grey Mullet Mugil 
cephalus contain $5.23,0.66,37.39,4.41$ and $38.71 \mathrm{ppm}$ for $\mathrm{Pb}, \mathrm{Cd}$, $\mathrm{As}, \mathrm{Cu}$ and $\mathrm{Fe}$, respectively. The muscles of Eels Anguilla anguilla contain $0.09,0.032,11.4,0.7,4.93 \mathrm{ppm}$ for $\mathrm{Pb}, \mathrm{Cd}, \mathrm{As}, \mathrm{Cu}$ and $\mathrm{Fe}$, respectively (Usero et al., 2003). These higher concentrations than those found in the present study may contribute to that the Grey mullet $M$. cephalus is detritivorous species that feeds on the accumulated organic matters (heavy pollutants), while the cel $A$. anguilla is Carnivorous species that feeds mainly on the crustaceans and Mollusks which accumulating high percentages of heavy metals in their tissues (Heath, 1987). However, Siganus fishes are herbivorous species that feed on phytoplankton, algae and aquatic herbs which contain traces of heavy metals because their short life cycle and their living in the water column (diluted pollutants). This conclusion agrees with Romeo et al. (1999) where they indicated that the concentration of heavy metals in fish muscles were higher in demersal fishes than in pelagic fishes. According to the international measurements (Kirt and Sawyer, 1991), it can be concluded that the heavy metal concentrations in both $S$. canaliculatus inhabiting the Arabian Gulf and S. rivulatus inhabiting the Red Sea were lower than the permissible concentration limits, and may be recommended that Siganus fishes is safe for Human consumption.

\section{Acknowledgements:}

The authors gratefully thank Dr. Al-Jedah, J. H. for his valuable assistance in the analysis of fatty acids and minerals.

\section{REFERENCES}

Alasalvar, C. ; Taylor, T. D. A. ; Zubcov, E. ; Shahidi, F. and Alexis, M. (2002). Differentiation of cultured and wild sea bass (Dicentrarchus labrax): total lipid content, fatty acid and trace mineral composition. Food Chem., 79: 145-150.

Al-Baharna, W. (1986). Fishes of Bahrain. Ministry of Commerce and Agriculture, Bahrain.

Al-Jedah, J. ; Ali, M. and Robinson, R. (1999). The nutritional importance to local communities of fish caught off the coast of Qatar. Nutrition and Food Sci., 6: 288-294. 
Al-Owafeir, M. (1999). The effects of dietary saponin and tannin on growth performance and digestion in Oreochromis niloticus and Clarias gariepinus. $\mathrm{PhD}$ Thesis, 220p. University of Stirling, Scotland.

Al-Saleh, I. and Shinwari, N. (2002). Preliminary report on the levels of elements in four fish species from the Arabian Gulf of Saudi Arabia. Chemosphere, 48: 749-755.

AOAC, (1995). Official Method of Analysis. $16^{\text {th }}$ ed. Association of Analytical Chemists. Washington, D.C., U.S.A.

Basson P. W. ; Burchard, J. E. ; Hardy, J. T. and Price, A. R. G. (1981). Biotopes of the western Arabian Gulf. Marine life and environments of Saudi Arabia. The Aramco department of loss prevention and environmental affairs, Dhahran, Saudi Arabia.

Bilecenoglu, M. (2002). Growth of marbled spinefoot Siganus rivulatus Forsskal, 1775 (Teleostei: Siganidae) introduced to Antalya Bay, eastern Mediterranean Sea (Turkey). Fish. Res., $54: 279-285$.

Boonyaratpalin, M. (1997). Nutrient requirements of marine food fish cultured in Southeast Asia. Aquacult., 151:283-313.

Canli, M. and Atli, G. (2003). The relationships between heavy metal $(\mathrm{Cd}, \mathrm{Cr}, \mathrm{Cu}, \mathrm{Fe}, \mathrm{Pb}, \mathrm{Zn}$ ) levels and the size of six Mediterranean fish species. Environ. Pollut., 121: 129-136.

Canli, M. and Furness, R. (1995). Mercury and cadmium uptake from seawater and from food by the Norway lobster Nephrops norvegicus. Environ. Toxicol. Chem., 14: 819-828.

Chan, K. M. (1995). Concentration of copper, zinc, cadmium and lead in rabbitfish (Siganus oramin) collected in Victoria Harbour. Mar. Pollut. Bull., 3I:277-280. 
Childs, M. T. and King, I. B. (1993). Dietary importance of fish and shell-fish, In Macrae, R., Robinson, R.K. and Sadler, M. (Eds.), Encyclopedia of food science, Food Techn. and Nutrit., Vol. 3, Academic Press, London.

Egan, H. ; Kirk, S. and Sawyer, R. (1981). Pearson's chemical analysis of food, $8^{\text {th }}$ ed., Churchill Livingstone, London.

El-Gammal, F. I. (1988). Age, growth and mortality of the rabbitfish Siganus rivulatus (Forssk.,1775) from the Red Sea. Bull. Inst. Oceanogr. Fish. Egypt, 14(1),13-21.

Elgasim, E. A. (1994). Processing potentialities of the Arabian Gulf fishes: (2) Fish Finger Production. Egyp. J. Sci., 9(10) 118 126.

Gessner, J. ; Wirth, M. ; Kirschbaum, F. ; Kruger A. and Patriche, N. (2002). Caviar composition in wild and cultured sturgeonsimpact of food sources on fatty acid composition and contaminant load. J. Applied Ichthy., 18:665-672.

Grigorakis, K. ; Alexis, M. ; Talyor, K. and Hole, M. (2002). Comparison of wild and cultured gilthead sea bream (Sparus aurata) composition, appearance and seasonal variations. Inter. J. Food Sci. Tech., 37:477-484.

Hardy, R. and King, I. (1989). Variation in n-3 fatty acid content of fresh and frozen salmon. Omega 3 News, 4:1-4.

Hashem, M. T. ; (1983). Biological studies on Siganus rivulatus (Forssk.) in the Red Sea. J. Faculty Mar. Sci., 3: 119-127.

Heath, A. (1987). Water pollution and fish physiology. CRC Press, Florida, USA.

IUPAC, (1979). International Union of Pure and Applied Chemistry. Standard Methods for Oils, Fats and Derivatives, sixth edition, Pergamon Press, UK. 
Kherunnisa, R. ; Qadri, S. ; Touheed, A. and Viqaruddin, A. (1996): Fatty acid profile of four marine fish species from Karachi coastal waters. J. Chem. Soc. Pak., 18:44-47.

Kirt, R. and Sawyer, R. (1991). Pearson's Composition and Analysis of Food $9^{\text {th }}$ ed. Churchill Livingtone, London.

Lai Man So, Cheung R. Y. and Chan K. M. (1999). Metal concentrations in tissues of Rabbitfish (Siganus oramin) collected from Tolo Harbour and Victoria Harbour in Hong Kong. Mar. pollut., 39:234-238.

Meeren, T. ; Klungsoyr, J. and Wilhelmsen, S. (1993). Fatty acid composition of unfed Cod larvae Gadis morhua L. and Cod larvae feeding on natural plankton in large enclosures. J. World Aquacult. Soc., 24:167-185.

Montano, N. ; Gavino, G. and Gavino, V. (2001). Polyunsaturated fatty acid contents of some traditional fish and shrimp paste condiments of the Philippines. Food Chem., 75:155-158.

$\mathrm{Ng}, \mathrm{W}$. ; Lim, P. and Boey, P. (2003). Dietary lipid and palm oil source affects growth, fatty acid composition and muscle $\alpha-$ tocopherol concentration of African catfish, Clarias gariepinus. Aquacult., 215: 229-243.

NRC, (National Research Council). (1985). Oil in the sea. Inputs fates and effects. National Academy Press, Washington Press, Washington, DC.

Olsen, R. and Henderson, R. (1997). Muscle fatty acid composition and oxidative stress indices of Arctic charr, Salvelinus alpinus (L.), in relation to dietary polyunsaturated fatty acid levels and temperature. Aquacult. Nutrit., 3:227-238.

Querijero, B. ; Teshima, S. ; Koshio, S. and Ishikawa, M. (1997). Utilization of monounsaturated fatty acid (18: $\ln -9$, oleic acid) by freshwater prawn Marobrachium rosenbergii (de Man) juveniles. Aquacult. Nutrit., 3:127-139. 
Ricker, W. E. (1975). Computation and interpretation of biological statistics of fish populations. Bull. Fish. Res. Board Can. $191,383$.

Romeo, M. ; Siau, Y. ; Sidoumou, Z. and Gnassia-Barelli, M. (1999). Heavy metal distribution in different fish species from the Mauritania coast. Sci. Total. Enviro., 232: 169-175.

SAS. (1990). Statistical analytical systems user's guide (Vol. 2). Carg, NC : SAS Institute Inc. USA.

Steffens, W. (1989). Principles of fish nutrition. Ellis Horwood Limited, England.

Uesro, J. ; Izquierdo, C. ; Morillo, J. and Gracia, I. (2003). Heavy metals in fish (Solea vulgaris, Anguilla anguilla and Liza aurata) from salt marshes on the southern Atlantic coast of Spain. Environ. Internation., 1069: 1-8.

Wodtke, E. (1981). Temperature adaptation of biological membranes. The effects of acclimatation temperature on the unsaturation of the main neurtal and charged phospholipids in mitochondrial membranes of the carp (Ciprinus carpio L.). Biochim. Biophys. Acta, 640:698-709.

Wray, T. (1979). Commercial fishes of Saudi Arabia. Saudi Fisheries Company, Ministry of Agriculture and Water Resources. Saudi Arabia.

Zaki, M. I. ; Massoud, A. A. ; Madkour, N. K. ; El-Fiky, N. K. and Elmesiry, G. E. (1996). The cyclic changes in the pituitary gland and gonads of Siganus rivulatus from the Red sea (Hurghada Area). J. KAU: Mar. Sci., vol.7, Special Issue: Symp. On Red Sea Mar. Environ., Jeddah, pp271-284. 
Table (1). Some biological aspects of $S$. canaliculatus and $S$. rivulatus harvested from the Arabian Gulf and Red Sea in Saudi Arabia.

\begin{tabular}{|l|c|c|}
\hline \multicolumn{1}{|c|}{ Items } & S. canaliculatus & S. rivulafus \\
\hline Range of fish length (cm) & $15-32$ & $15-27$ \\
\hline Mean fish length (cm) & $22.93^{\mathrm{a}} \pm 2.75$ & $20.23^{\mathrm{b}} \pm 1.84$ \\
\hline Range of fish weight (gm) & $54-519$ & $52-248$ \\
\hline Mean fish weight (gm) & $152.56^{\mathrm{a}} \pm 63.87$ & $109.69^{\mathrm{b}} \pm 30.17$ \\
\hline Frequency & 270 & 200 \\
\hline Length-weight regression parameters: & & 0.013 \\
$\mathrm{r}$ & 3.28 & 2.99 \\
\hline Absolute Condition Factor (Kc) & 0.9978 & 0.9589 \\
\hline Relative Condition Factor (Kn) & $1.29^{\mathrm{a}} \pm 0.09$ & $1.24^{\mathrm{b}} \pm 0.07$ \\
\hline Range flesh weight (gm) & $1.06^{\mathrm{a}} \pm 0.07$ & $0.99^{\mathrm{a}} \pm 0.06$ \\
\hline Mean flesh weight (gm) & $26^{\circ}-300$ & $25^{2}-135$ \\
\hline Mean flesh percentage (Dress-out \%) & $50.39^{\mathrm{a}} \pm 3.75$ & $48.93^{\mathrm{b}} \pm 3.24$ \\
\hline
\end{tabular}

The values are the mean \pm Standard deviation followed by the same letter within a raw, are not significantly different $(P>0,05)$.

Table (2). Proximate analysis of flesh and body entire of $S$. canaliculatus and S. rivulatus in Saudi Arabia.

\begin{tabular}{|l|c|c|c|c|}
\hline \multirow{2}{*}{ Items } & \multicolumn{2}{|c|}{ S. canaliculatus } & \multicolumn{2}{c|}{ S. rivulatus } \\
\cline { 2 - 5 } & Body entire & Muscles & Body entire & Muscles \\
\hline Fresh matter (gm): & 100 & 100 & 100 & 100 \\
\hline Moisture (\%) & $78.14 \pm 0.03$ & $78.10 \pm 2.29$ & $78.09 \pm 0.49$ & $78.95 \pm 1.19$ \\
\hline Protein (\%) & $14.17 \pm 0.16$ & $18.26 \pm 1.92$ & $14.96 \pm 0.41$ & $18.85 \pm 1.06$ \\
\hline Fat (\%) & $4.45 \pm 0.15$ & $2.70 \pm 0.31$ & $3.64 \pm 0.07$ & $1.37 \pm 0.06$ \\
\hline ASH (\%) & $3.23 \pm 0.17$ & $0.94 \pm 0.07$ & $3.31 \pm 0.02$ & $0.83 \pm 0.08$ \\
\hline
\end{tabular}

The values are the mean \pm Standard deviation 
Table (3). The fatty acids percentage $(\mathrm{g} / 100 \mathrm{~g}$ total lipids) in the flesh of $S$. comaliculatus and S. rivulatus in Saudi Arabia.

\begin{tabular}{|c|c|c|}
\hline \multirow{2}{*}{ Fatty acid } & \multicolumn{2}{|c|}{ Concentration (\%) } \\
\cline { 2 - 3 } & S. canaliculatus & S. rivulatus \\
\hline C 12:0 & $0.35 \pm 0.04$ & $1.09 \pm 0.11$ \\
\hline C 14:0 & $4.34 \pm 0.04$ & $7.55 \pm 0.08$ \\
\hline C $16: 0$ & $31.90 \pm 0.20$ & $32.00 \pm 0.50$ \\
\hline C 18:0 & $5.61 \pm 0.10$ & $3.94 \pm 0.14$ \\
\hline C 24:0 & $3.86 \pm 0.29$ & $5.74 \pm 0.11$ \\
\hline Total saturated & $46.06 \pm 0.13$ & $\mathbf{5 0 . 3 2 \pm 0 . 1 9}$ \\
\hline C 16:1 & $7.51 \pm 0.17$ & $8.02 \pm 0.07$ \\
\hline C 18:1 & $10.40 \pm 0.25$ & $11.09 \pm 0.72$ \\
\hline C 20:1 & $0.71 \pm 0.02$ & $0.24 \pm 0.01$ \\
\hline Total monounsaturated & $\mathbf{1 8 . 6 2} \pm \mathbf{0 . 1 5}$ & $\mathbf{1 9 . 3 5} \pm \mathbf{0 . 2 7}$ \\
\hline C 18:2 & $2.17 \pm 0.12$ & $2.25 \pm 0.05$ \\
\hline C 18:3 & $0.66 \pm 0.07$ & $1.26 \pm 0.12$ \\
\hline Total polyunsaturated & $\mathbf{2 . 8 3} \pm \mathbf{0 . 1 0}$ & $\mathbf{3 . 5 1} \pm \mathbf{0 . 0 9}$ \\
\hline
\end{tabular}

The values are the mean \pm Standard deviation

Table (4). Concentration of minerals and heavy metals in the flesh of $S$. canaliculatus and $S$ rivulatus in Saudi Arabia.

\begin{tabular}{|l|c|c|}
\hline \multirow{2}{*}{ Elements } & \multicolumn{2}{|c|}{ Concentration in ppm } \\
\cline { 2 - 3 } & S. canaliculatus & S. rivulatus \\
\hline Sodium (Na) & $856.412 \pm 2.73$ & $585.144 \pm 2.89$ \\
\hline Potassium (K) & $5044.436 \pm 12.87$ & $2589.548 \pm 58.31$ \\
\hline Magnesium (Mg) & $240.945 \pm 0.90$ & $194.543 \pm 2.23$ \\
\hline Calcium (Ca) & $453.060 \pm 4.05$ & $544.339 \pm 5.24$ \\
\hline Lead (Pb) & $0.034 \pm 0.00$ & $0.001> \pm 0.00$ \\
\hline Zinc (Zn) & $5.262 \pm 0.00$ & $2.501 \pm 0.01$ \\
\hline Copper (Cu) & $1.551 \pm 0.06$ & $0.598 \pm 0.06$ \\
\hline Manganese (Mn) & $0.466 \pm 0.01$ & $0.268 \pm 0.03$ \\
\hline Iron (Fe) & $6.045 \pm 0.21$ & $19.779 \pm 0.83$ \\
\hline Cadmium (Cd) & $0.001> \pm 0.00$ & $0.001> \pm 0.00$ \\
\hline Arsenic (As) & $0.001> \pm 0.00$ & $0.001> \pm 0.00$ \\
\hline Aluminium (Al) & $0.001> \pm 0.00$ & $0.001> \pm 0.00$ \\
\hline
\end{tabular}

The values are the mean \pm Standard deviation. 


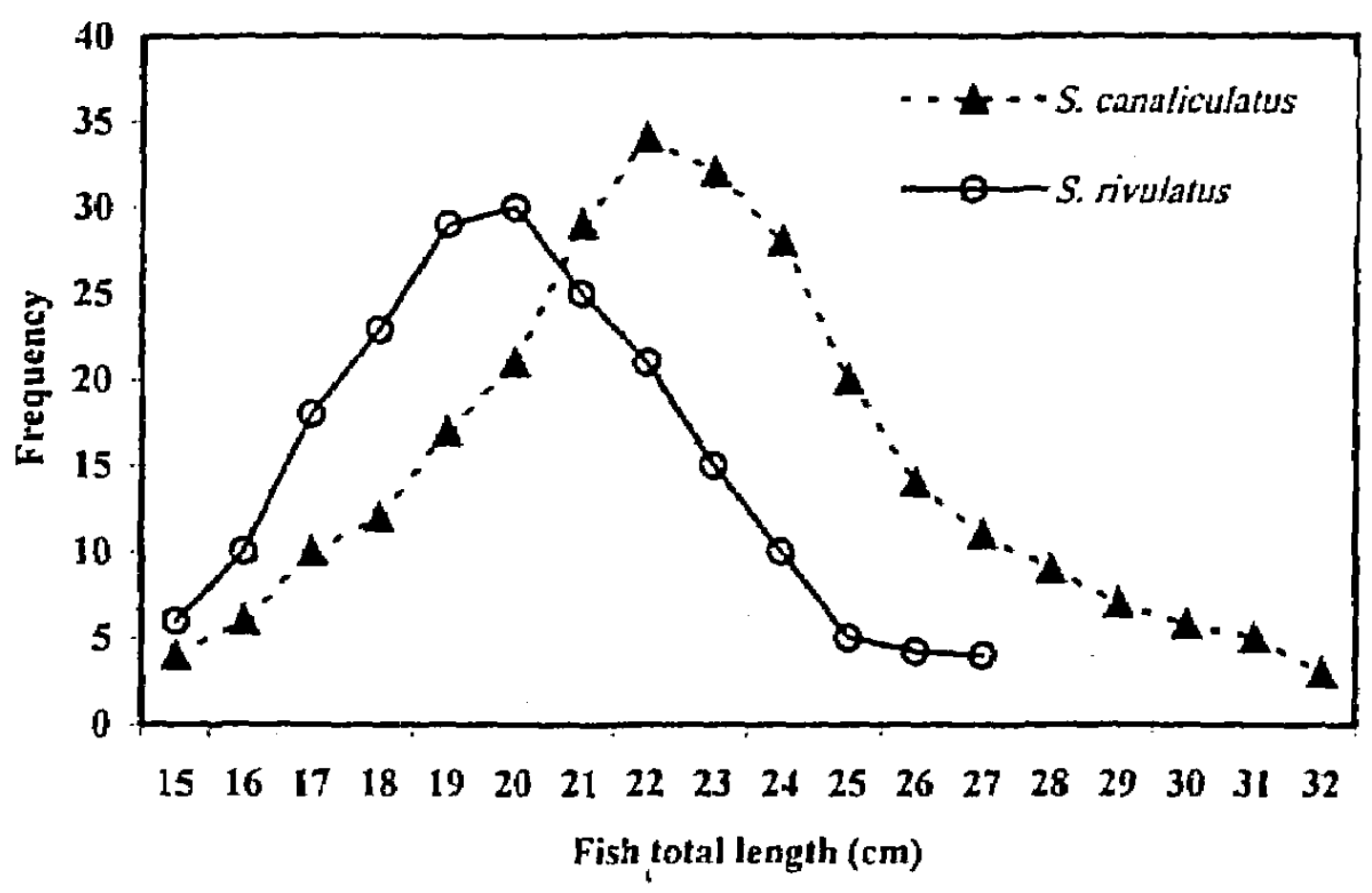

Figure (1). Length frequency distribution of $S$. canaliculatus and $S$. rivulatus harvested from the Arabian Gulf and Red Sea in Saudi Arabia.

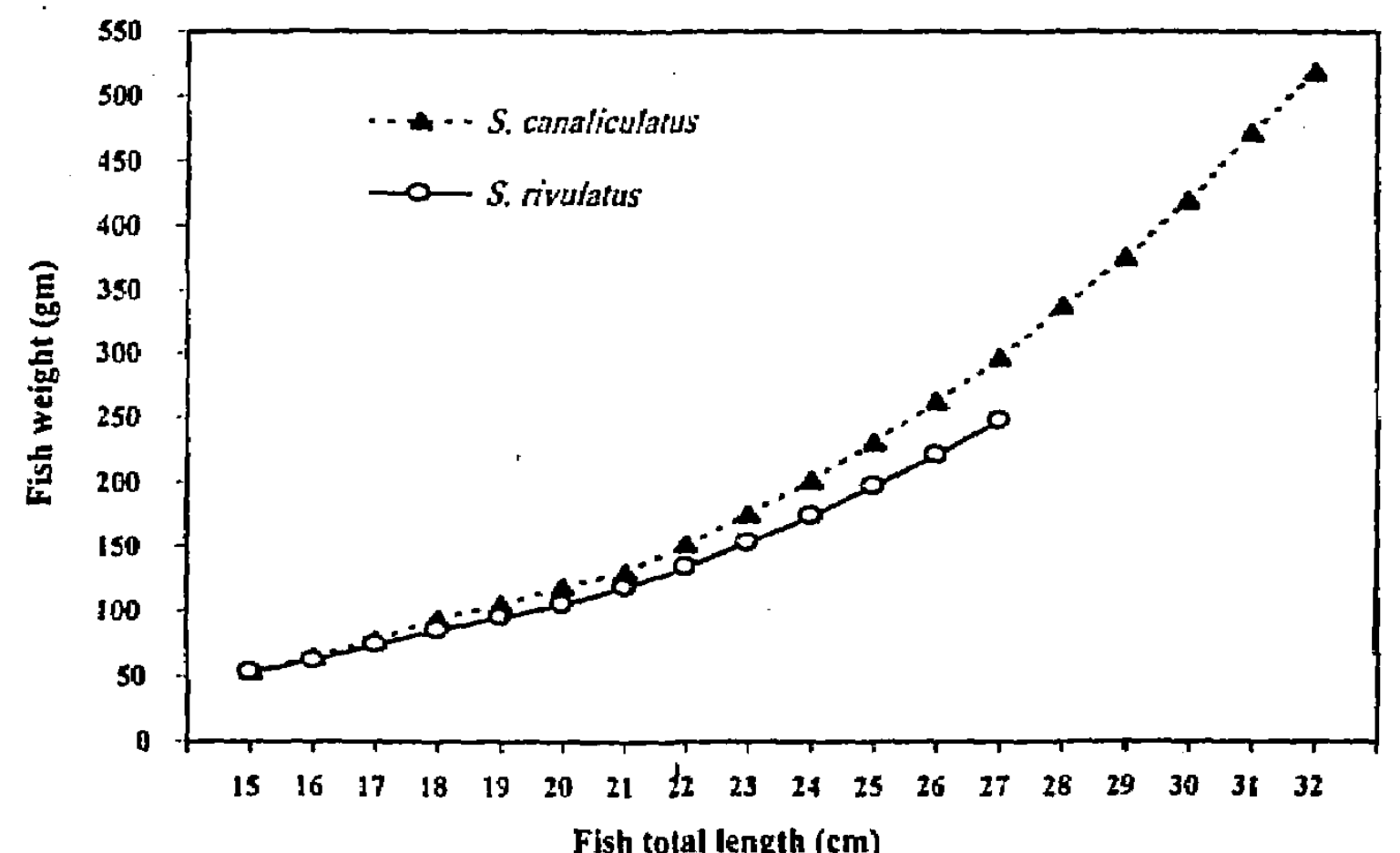

Figure (2). Length-weight relationship of $S$. canaliculatus and $S$. rivulatus harvested from the Arabian Gulf and Red Sea in Saudi Arabia. 


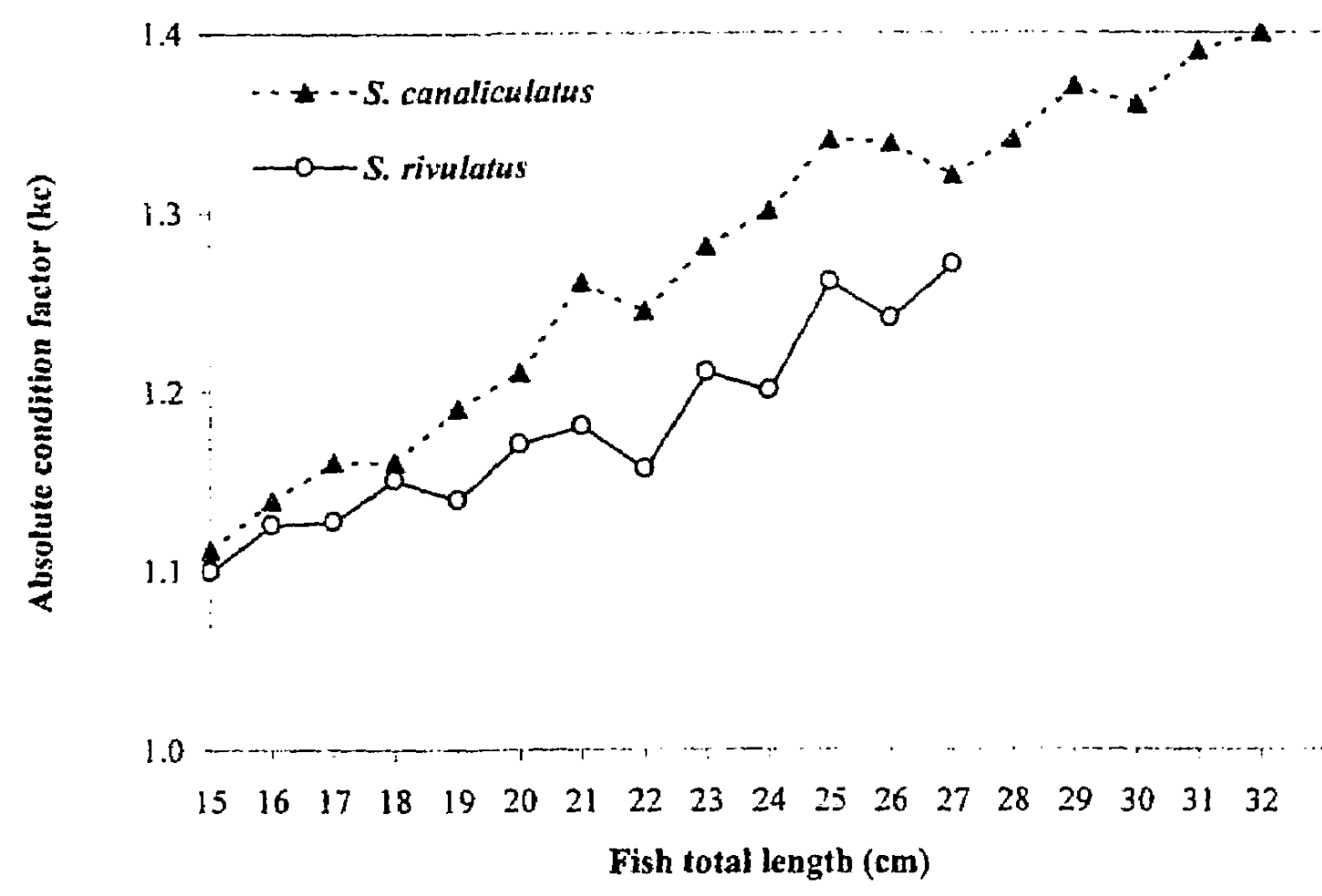

Figure (3): Absolute condition factor $(\mathrm{Kc})$ of $S$. canaliculatus and $S$. rivulatus harvested from the Arabian Gulf and Red Sea in Saudi Arabia.

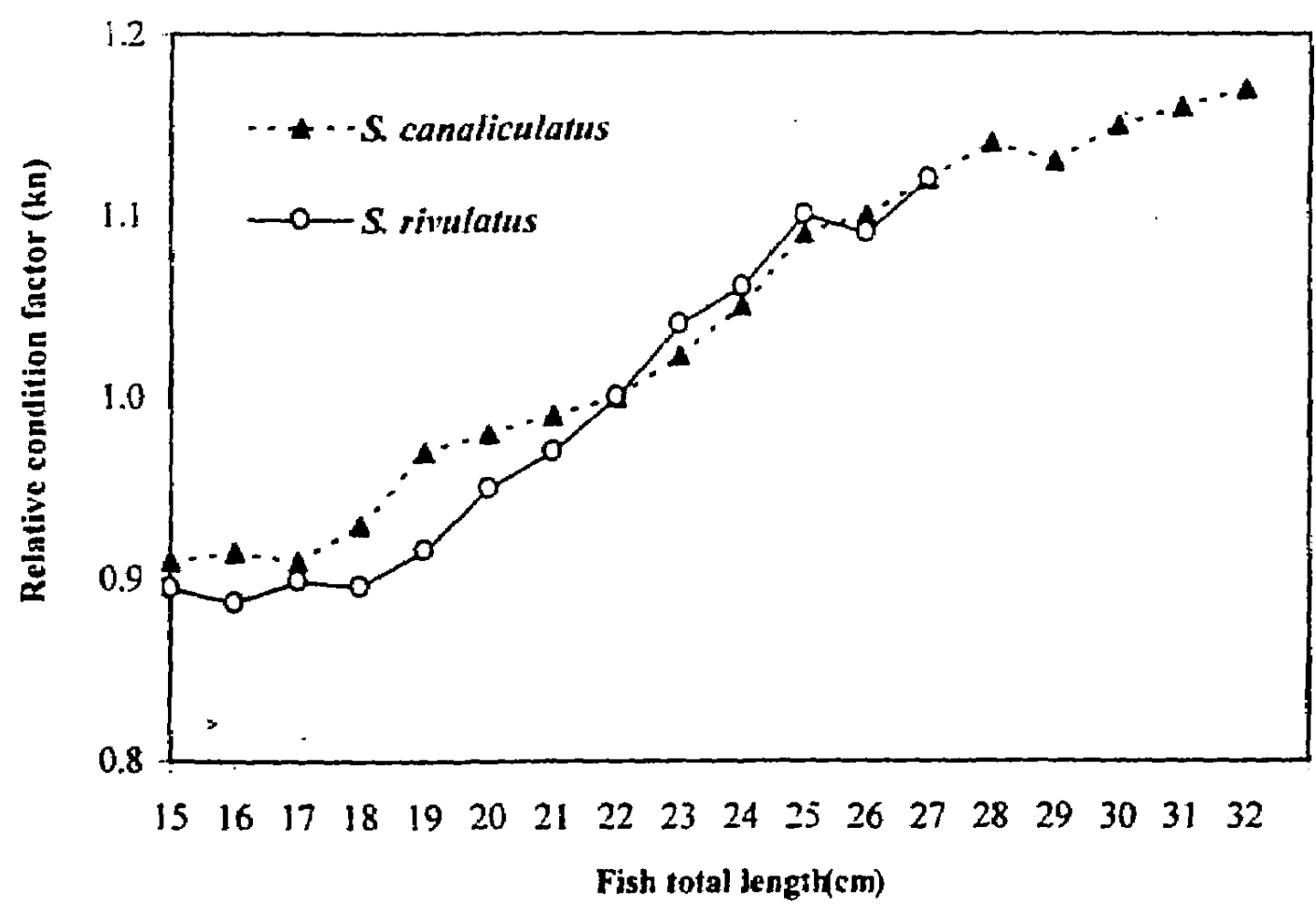

Figure (4): Relative condition factor $(K n)$ of $S$. canaliculatus and $S$. rivulatus harvested from the Arabian Gulf and Red Sea in Saudi Arabia. 


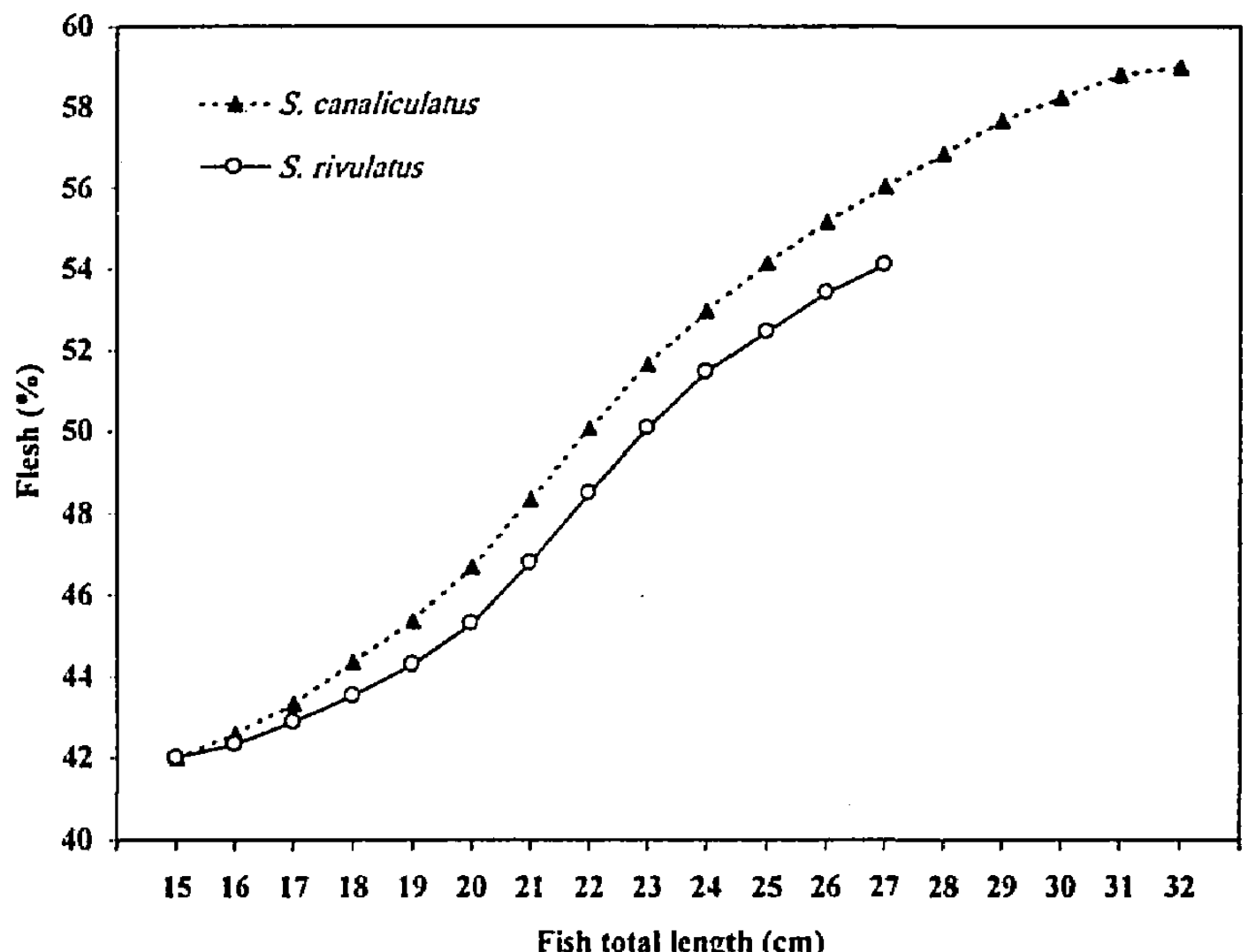

Figure (5). The flesh percentage (muscles \%) of $S$. canaliculatus and $S$. rivulatus harvested from the Arabian Gulf and Red Sea in Saudi Arabia. 